\title{
Modeling approach to study singlehood phenomenon among elderly people
}

\author{
Galina Barysheva ${ }^{1}$, Lubov Ivankina ${ }^{1}$, Evgeny Monastyrny ${ }^{1}$, and Elena Klemasheva ${ }^{1, *}$ \\ ${ }^{1}$ National Research Tomsk Polytechnic University, 30, Lenin avenue, 634050, Tomsk, Russia
}

\begin{abstract}
The paper studies the loneliness phenomenon as a systemic problem of economic, social and emotional wellbeing of elderly people. The aim of this paper is to substantiate the modeling methodology of loneliness among elderly people, show the structure and content of its vision model. Loneliness is viewed as a systemic problem related to the daily practices of the elderly person, his well-being or disadvantage in the economic, social and emotional aspects. The authors propose the level search model for studying the loneliness phenomenon and consider its practical use in the evaluation of singlehood among elderly people. Methodological principles are identified to trace a connection between the inner and outer nature of singlehood.
\end{abstract}

\section{Introduction}

In modern society, a comparison of the problem of singlehood with society's plague [1-3] emphasizes external causes of singlehood which appears due to socioeconomic and sociocultural processes.

If it is assumed that the problem of singlehood among elderly people is based on external reasons, its connection with the human involvement in the main socioeconomic spheres of life is obvious. It is a case of external interferences in this social group and creation of conditions leading to the fact that some of elderly people will feel discomfort and strong frustration relative to their socio-economic positions. In this formulation of the question, the relevance of this work is determined by both the necessity of identification of negative factors exacerbating a feeling of loneliness and development of social and economic measures to protect this social group from this feeling.

According to the model of psychosocial stages of personality development (stages of life) created by Erikson [4], people in the age group of 20 to 25 face the feeling of loneliness at the sixth stage of life as the established response to ineffective addressing the situation due to their inability to enter into trust relations with other people. Those who successfully come out of this stage will not subsequently experience this problem since they perceive events occurring in their life at a constructive, interpersonal relations, self-responsibility, and concern for others. In adulthood, due to earlier stages of life, singlehood is of contextual nature.

A feeling of loneliness describes in this case an imbalance caused by experiencing events occurring in the life of a person entering the pension age and releasing from professional employment (loss of job, achieved status and social relations).
The literature review on the problem of singlehood shows that there are many approaches and models which investigate mostly the inner nature of singlehood [5-8].

External reasons and factors of singlehood are investigated in terms of disturbed interpersonal communication [9-14]. Sadler and Johnson reported that loneliness is an experience involving a total and often acute feeling that constitutes a distinct form of selfawareness signaling a break in the basic network of the relational reality of self-world.

Upon the whole, the existing theoretical models which reflect the phenomenon under study do not provide a comprehensive explanation to singlehood of elderly people.

Authors believe that research results on the development and implementation of the complex model of the singlehood phenomenon will be interesting to the scientific society involved in investigations into different and sometimes narrow issues of elderly people. The results obtained for factors causing this negative feeling can serve as an information basis for making management decisions at regional and federal levels.

The aim of this work is to substantiate the methodological approach to a complex modeling of singlehood and propose the procedure of evaluating singlehood among elderly people.

In terms of this aim the following purposes should be accomplished.

1) Identification of methodological bases principles of the model development which considers socioeconomic, psychological and physiological facets of elderly people existence.

2) Development of a multi-level model of the singlehood phenomenon and form on its basis the evaluation procedure for the singlehood level among elderly people, with specifying key indicators.

\footnotetext{
Corresponding author: eik15@tpu.ru
} 
Evaluation of the singlehood level is an integrated indicator of dissatisfaction of elderly people who suffer from loneliness in the main, vital social sectors.

\section{Modeling methodology and principles of singlehood among elderly people}

The proposed modeling methodology of singlehood among elderly people is based on the Husserl's concept of life-world, which allows us to interconnect the reality (external factor) and relation to it (internal factor). This approach shows agreement with the Erikson's concept of psychosocial stages of the personality development, in accordance to which the loneliness in elderly age is caused by socioeconomic and social processes which influence the human emotions.

Sadler and Johnson who studied the nature of singlehood clarified the concept of life-world in the context of the human experience and defined the life world as an intentional, structured network which establishes universal limits inside which events become meaningful [15]. According to Sadler and Johnson, this concept is consistent with the human involvement in various spheres of life, namely economic, social, psychological, and physiological. They note that the concept of intentionality considers the life world of a personality as a world with a pluralistic structure. Pluralism unveils the existentialistic potentials which guide a person in his or her life [15].

In terms of the concept of life-world, we regard singlehood as a complex systemic phenomenon arising from unmet needs of elderly people which appear in various spheres of his or her everyday life. This approach is consistent with the details of the singlehood concept substantiated in the work of Elyutina and Trofimova [10].

The theoretical and systemic conception of singlehood was first formulated by Flanders in 1982 [16]. It is based on a combination of interacting elements which form a feedback mechanism which, in turn, coordinates both individual and contextual behavioral motives.

When addressing singlehood in the context of the life world, we can detect its connection with the environment which transfers its influence to the inner nature of the human experience. The process of the growing impact on spheres relating to internal factors of singlehood are driven by such external factor as liberation from making socio-economic and political decisions which determines the standards of communication.

Based on the nature of singlehood of elderly people, a deterministic, multifactor model is the most appropriate for understanding the singlehood phenomenon of this group of people. A choice of this model type is determined by the nature of singlehood substantiated by Sermat, who defined loneliness as "an experienced discrepancy between the kinds of interpersonal relationships the individuals perceive themselves as having and the kind of relationships they would like to have" [17].
Governing parameters which determine the model of singlehood among elderly people include institutional spheres representing a combination of all kinds of activity oriented towards needs the meeting of which thereby provides the respective function in the human life.

The institutional sphere defines sustainable relationships between objects involved. The following institutional spheres determine the parameters of the deterministic model:

- economic sphere, a combination of relationships and interactions between objects and subjects involved in the process of economic production, exchange, and consumption;

- social sphere, a combination of relationships and interactions between social groups;

- psychological sphere, a combination of psychological processes and conditions emerging during the process of emotional and information exchange between internal and external factors of the life;

- physiological sphere, a consistent functioning of important processes at a level of the life support.

Ecological, regulatory, and sociocultural factors with a general orientation and indirect effect are meaningful for experiencing loneliness by elderly people and form their inhabitable environment.

How these spheres are connected with each other? According to the deterministic model, the influence of one sphere on another in the formation of the singlehood phenomenon is of linear nature, with a unidirectional snowball effect. This influence is identified as events in the human life accompanied by negative experiences leading to diseases and deterioration of the health.

At present, a large body of evidence has been accumulated by the scientific community, which confirms the influence of the event experience leading to the feeling of loneliness affecting the human health. Berkman et al. [7] highlighted the links between health hazards and lack in diversity of social communication. Perissinotto et al. [18] noted the connection of loneliness and increased death risk with the functional decline. In the work [19], Cacioppo et al. experimentally proved that loneliness is a specific risk factor for depressive symptom. Based on the literature review of more than 140 research papers, Holt-Lunstad et al. [20] proved that people with positive social relationships are more likely to possess a longer length of life.

In order to detect the connection between the inner and outer nature of singlehood, the model construction is based on the following methodological principles:

- dialectic interconnection and interconditionality of singlehood as an individual and social phenomenon actualized through utilizing a factorial approach which considers singlehood as resulting from the internal and external factors;

multidimensionality (economic, social, psychological, physiological spheres) of the singlehood phenomenon connected with factors affecting the quality of the emotional sufferings in the conditions of the certain sociocultural environment;

- institutional economics which considers the singlehood phenomenon at a level of the individual, 
social group and society via the interaction between the institutional spheres, namely economic, social, psychological, physiological;

- a comprehensive analysis of the four institutional spheres considered as determinants of the main content of the single hood phenomenon.

The process of the growing impact on spheres relating to internal factors of singlehood is driven by such external factor as liberation from socio-economic activity which entering the pension age.

The model of singlehood of elderly people can be represented by the level model more comprehensively and systemically.

\section{Estimation model of singlehood phenomenon among elderly people}

The onion model presented in Fig. 1 is selected from level models for the best description of the singlehood phenomenon in the discrete deterministic process of sequential changes.

In terms of the onion model, singlehood is the integral system with institutional spheres connected with each other. Each layer of the model represents the institutional sphere conditioning the emergence of the feeling of loneliness.

The first level of the onion model includes parameters of the economic sphere; the second level includes the social sphere; the third level represents the psychological sphere and the fourth, the onion nucleus is the physiological sphere, which describes the state of ill health stipulated by experiencing events acquired in preceded institutional spheres.

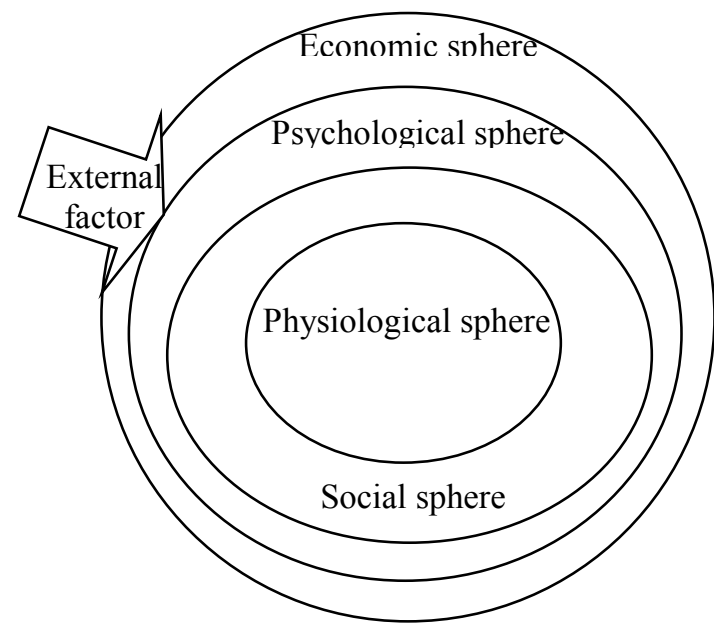

Fig 1. Onion model of singlehood phenomenon formation

As distinguished from the influence of institutional spheres on the individual life of each person, in the case of social groups, strata, and purposive sample, the complex, external factors influence first the economic sphere. Changes in this sphere modify the social sphere of communication of and relations between elderly people, whereas their combined effect predetermines changes in psychological and physiological spheres.

The parameters and variables of the deterministic model are definite, not random values. In our case they represent indicators of the singlehood phenomenon summarized in Table 1.

In order to construct the discrete deterministic model of singlehood, let use a tetrahedron which forms a rigid, statistically defined structure included in the environment. Each side of this tetrahedron is the institutional component (economic, social, psychological, and physiological) of the human life. The inner space of the tetrahedron is the subject matter of the life comprising both everyday practices and the attitude of individuals as rational beings to manifestations of the external world and inner experiences. The external world includes all other factors not relating to the indicated institutional spheres, namely political, ecological, spiritual, etc.

Depending on the purposes of this study, the threedimensional model of singlehood can be presented in a plane as shown in Fig. 2.

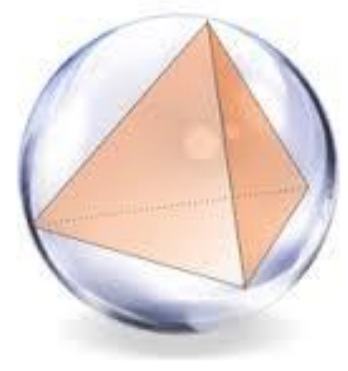

Three-dimensional model

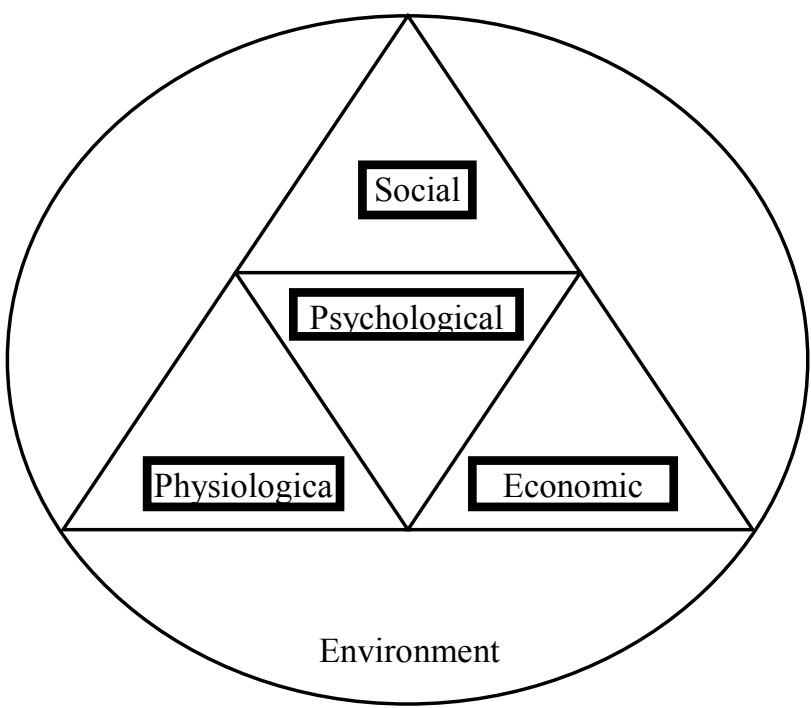

Fig 2. Discrete deterministic model of singlehood phenomenon among elderly people. Vision for the phenomenon

Our research focuses on the psychological component (Fig. 2) of the singlehood phenomenon model. Within the emotional evaluative aspect, this component interprets the events experienced by an elderly individual which are important to his or her wellbeing both today and in the future.

The focus on the evaluative aspect in the attitude to ongoing events in the life of elderly people, provides its impact both on the impartial deterioration and improvement of economic, social, and physiological spheres. This characterizes the singlehood phenomenon 
model as a feedback system, which, in general, corresponds to the black box model of management, in which the transforming components of the process are dominating elements.

The proposed discrete deterministic models presented in Fig. 1 and 2 describe the inner structure of this phenomenon and the influence of the external factors on the loneliness formation. These models relate to models of the highest level of generalization, i.e. methodological models of the singlehood phenomenon as a whole.

At the same time, such models are difficult to use in both qualitative and quantitative analyses. In order to analyze the singlehood phenomenon, it is advisable to migrate to another level and utilize tools of the systems analysis.

While retaining the main parameters of the institutional models, let us use the analysis and synthesis process to the object of 'Individual. Subject matter of life' presented in Fig. 3 which depicts the method of evaluation of the singlehood phenomenon. Stage-bystage we decompose this object into internal and external factors, institutional spheres and indicators of their evaluation.

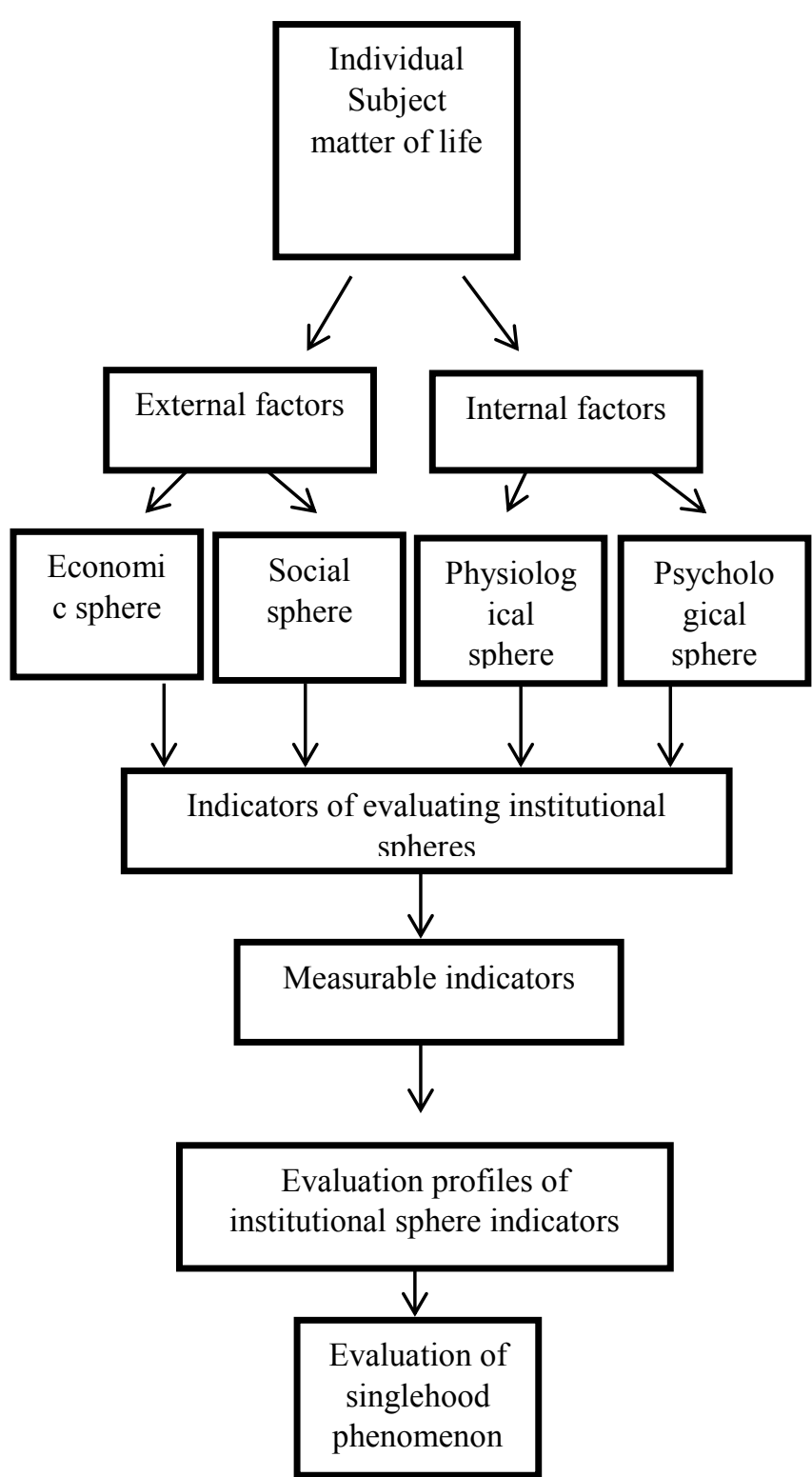

Fig 3. Systemic model of singlehood phenomenon. Method of evaluation

At this stage of modeling, we use the main ideas of models of the highest level of generalization up to the definition of the main processes ongoing in the institutional spheres and their interaction with the environment. Decomposition of the object ends with the choice of measurable indicators which can be both objective and subjective. The former include statistical data and the latter are data of the opinion poll and psychological tests.

The next stage of modeling based on the combination of measurable indicators, is the evaluation synthesis of individual indicators and the object as a whole. At this stage, the most important issue of this analysis is the development of the normative model to compare the data obtained. However, these issues are just beyond the 
scope of this research and will be discussed in further research.

The literature review in the area of interest as well as our experience allow us to propose a system of indicators of the singlehood phenomenon which differentiates the institutional spheres. These indicators are given in Table 1.

Table 1. Indicators of the singlehood phenomenon.

\begin{tabular}{|c|c|c|c|}
\hline $\begin{array}{l}\text { Economi } \\
\text { c sphere }\end{array}$ & $\begin{array}{l}\text { Social } \\
\text { sphere }\end{array}$ & $\begin{array}{l}\text { Psycholog } \\
\text { ical sphere }\end{array}$ & $\begin{array}{l}\text { Physiological } \\
\text { sphere }\end{array}$ \\
\hline $\begin{array}{l}\text { Labor } \\
\text { activity } \\
\text { (work) }\end{array}$ & $\begin{array}{l}\text { Leisure } \\
\text { and self- } \\
\text { actualiz } \\
\text { ation }\end{array}$ & $\begin{array}{l}\text { Self- } \\
\text { evaluation }\end{array}$ & $\begin{array}{l}\text { Medicate state } \\
\text { satisfaction }\end{array}$ \\
\hline $\begin{array}{l}\text { Pension } \\
\text { maintena } \\
\text { nce }\end{array}$ & $\begin{array}{l}\text { Social } \\
\text { activity }\end{array}$ & $\begin{array}{l}\text { Well- } \\
\text { being- } \\
\text { activity- } \\
\text { mood }\end{array}$ & $\begin{array}{l}\text { Expected length } \\
\text { of life (number } \\
\text { of years) }\end{array}$ \\
\hline State aid & $\begin{array}{l}\text { Degree } \\
\text { of } \\
\text { personal } \\
\text { relevanc } \\
\text { e in the } \\
\text { society }\end{array}$ & $\begin{array}{l}\text { Perspectiv } \\
\text { es }\end{array}$ & $\begin{array}{l}\text { Physical } \\
\text { activity } \\
\text { including } \\
\text { physical culture } \\
\text { and sport }\end{array}$ \\
\hline $\begin{array}{l}\text { Participat } \\
\text { ion } \\
\text { labour } \\
\text { activity, } \\
\text { househol } \\
\text { d }\end{array}$ & $\begin{array}{l}\text { Trust in } \\
\text { the } \\
\text { instituti } \\
\text { ons of } \\
\text { governa } \\
\text { nce }\end{array}$ & Mood & $\begin{array}{l}\text { Наличие } \\
\text { хронических } \\
\text { заболеваний }\end{array}$ \\
\hline Inflation & $\begin{array}{l}\text { Choice } \\
\text { of } \\
\text { religion } \\
\text { and } \\
\text { public } \\
\text { events }\end{array}$ & $\begin{array}{l}\text { Trust in } \\
\text { others }\end{array}$ & $\begin{array}{l}\text { Access to } \\
\text { quality health } \\
\text { care } \\
\text { and essential m } \\
\text { edicines }\end{array}$ \\
\hline $\begin{array}{l}\text { Capital } \\
\text { formatio } \\
n\end{array}$ & $\begin{array}{l}\text { Social } \\
\text { assistan } \\
\text { ce and } \\
\text { mutual } \\
\text { aid }\end{array}$ & $\begin{array}{l}\text { Acceptanc } \\
\text { e of nature } \\
\text { laws }\end{array}$ & $\begin{array}{l}\text { Human-friendly } \\
\text { environment }\end{array}$ \\
\hline
\end{tabular}

Another stage is the development of the official model as a system of indicators which allow using methods of mathematical statistics (cluster, factor and regression analyses). In Russia, the sources of the quantitative and qualitative information are the data given by the federal and regional statistics, data obtained from the integrated survey of life conditions and social studies, including the Tomsk region, performed within the Project 'Economic, Social and Emotional Wellbeing of Elderly People' (2014-2018). The Project is implemented by the International Research Laboratory of Wellbeing Improvement Technologies of Tomsk Polytechnic University [9].

The choice of indicators and data gathering in Russia is another stage including further publications. However, at present we can already demonstrate the principle of selecting indicators as presented in Table 2.
Table 2. Indicators and parameters of the singlehood phenomenon.

\begin{tabular}{|c|c|}
\hline Indicators & Parameters \\
\hline \multirow{5}{*}{$\begin{array}{l}\text { Labour } \\
\text { activity } \\
\text { (work) }\end{array}$} & Labour activity satisfaction \\
\hline & Labour conditions \\
\hline & Labour safety \\
\hline & Labour career after award of pension \\
\hline & Labour career for early retirement \\
\hline \multirow{5}{*}{$\begin{array}{l}\text { Social } \\
\text { activity }\end{array}$} & Involvement in tourist or round trips \\
\hline & Visiting different events \\
\hline & $\begin{array}{l}\text { Computer knowledge and the } \\
\text { Internet use }\end{array}$ \\
\hline & Family status \\
\hline & $\begin{array}{l}\text { Telecommunication facilities and } \\
\text { TV }\end{array}$ \\
\hline \multirow{7}{*}{ Perspectives } & Attitude to perception of the future \\
\hline & $\begin{array}{l}\text { Acceptance of life as it is, a desire to } \\
\text { take from life everything he/she } \\
\text { wants }\end{array}$ \\
\hline & $\begin{array}{l}\text { Difficulties due to health reasons in } \\
\text { involvement in social life and leisure } \\
\text { compensated by other useful activity }\end{array}$ \\
\hline & $\begin{array}{l}\text { Spare time for doing activities from } \\
\text { which a person enjoys }\end{array}$ \\
\hline & $\begin{array}{l}\text { Self-perception as a person the } \\
\text { family members feel the need of }\end{array}$ \\
\hline & $\begin{array}{l}\text { Getting satisfaction from obtained } \\
\text { results every day }\end{array}$ \\
\hline & $\begin{array}{l}\text { Interest in something, a desire to } \\
\text { learn about new things }\end{array}$ \\
\hline \multirow{5}{*}{$\begin{array}{l}\text { Human- } \\
\text { friendly } \\
\text { environment }\end{array}$} & $\begin{array}{l}\text { Thinking of living conditions in an } \\
\text { inhabited locality }\end{array}$ \\
\hline & $\begin{array}{l}\text { A description of living conditions of } \\
\text { households }\end{array}$ \\
\hline & $\begin{array}{l}\text { Household-provided estimation of } \\
\text { the state of residential } \\
\text { accommodation occupied by } \\
\text { households }\end{array}$ \\
\hline & $\begin{array}{l}\text { Household-provided estimation of } \\
\text { the state of the outdoor space }\end{array}$ \\
\hline & $\begin{array}{l}\text { Household-provided estimation of } \\
\text { the state of equipment inside the } \\
\text { house }\end{array}$ \\
\hline
\end{tabular}

The practical approval of the model of the singlehood evaluation among elderly people is implemented in the elaborated inquiry of social research. One of the purpose of this inquiry is the identification of factors affecting the feeling of loneliness, its stability and incidence at this stage of the human life [9]. Table 3 summarizes some of the research results which show a possibility of evaluating indicators which characterize the singlehood phenomenon observed among elderly people. 
Table 3. Parameters of 'Perspectives' indicator.

\begin{tabular}{|l|l|l|l|}
\hline $\begin{array}{l}\text { Affirmation } \\
\mathrm{t}\end{array}$ & $\begin{array}{l}\text { Agreemen } \\
\text { Partial } \\
\text { agreemen } \\
\mathrm{t}\end{array}$ & $\begin{array}{l}\text { Disagreem } \\
\text { ent }\end{array}$ \\
\hline $\begin{array}{l}\text { Positive in } \\
\text { thinking in } \\
\text { perception } \\
\text { of the future }\end{array}$ & $\begin{array}{l}30 \% \\
\text { (hope, } \\
\text { optimism) }\end{array}$ & $\begin{array}{l}45.3 \% \\
\text { (coolly, } \\
\text { without } \\
\text { hope) }\end{array}$ & $\begin{array}{l}23.1 \% \\
\text { (worry, } \\
\text { despair) }\end{array}$ \\
\hline $\begin{array}{l}\text { Acceptance } \\
\text { of life as it } \\
\text { is, a desire } \\
\text { to take from } \\
\text { life } \\
\text { everything } \\
\text { he/she wants }\end{array}$ & $71 \%$ & $18.8 \%$ & $11.8 \%$ \\
\hline $\begin{array}{l}\text { Difficulties } \\
\text { due to } \\
\text { health } \\
\text { reasons in } \\
\text { involvement } \\
\text { in social life } \\
\text { and leisure } \\
\text { compensate } \\
\text { d by other } \\
\text { useful } \\
\text { activity }\end{array}$ & $74.5 \%$ & $16 \%$ & $5.8 \%$ \\
\hline $\begin{array}{l}\text { Spare time } \\
\text { for doing } \\
\text { activities } \\
\text { from which } \\
\text { a person } \\
\text { enjoys }\end{array}$ & $89 \%$ & $8.8 \%$ & $2.2 \%$ \\
\hline $\begin{array}{l}\text { Self- } \\
\text { perception } \\
\text { as a person } \\
\text { the family } \\
\text { members } \\
\text { feel the need } \\
\text { of }\end{array}$ & $89.7 \%$ & $6.3 \%$ & \\
\hline $\begin{array}{l}\text { Getting } \\
\text { satisfaction } \\
\text { from } \\
\text { obtained } \\
\text { results every } \\
\text { day }\end{array}$ & $77.5 \%$ & $17.5 \%$ & \\
\hline $\begin{array}{l}\text { Interest in } \\
\text { something, a } \\
\text { desire to } \\
\text { learn about } \\
\text { new things }\end{array}$ & & & \\
\hline
\end{tabular}

Table 3 contains percentage of answers denoting agreement, partial agreement, and disagreement with affirmations given in the first column. The profile of 'Perspectives' indicator is presented in Fig. 4. Measurable indicators include agreement with the affirmation offered. The total evaluation of 'Perspectives' indicator is calculated as an average number for all indicators as indicated by a horizontal line in Fig. 4.

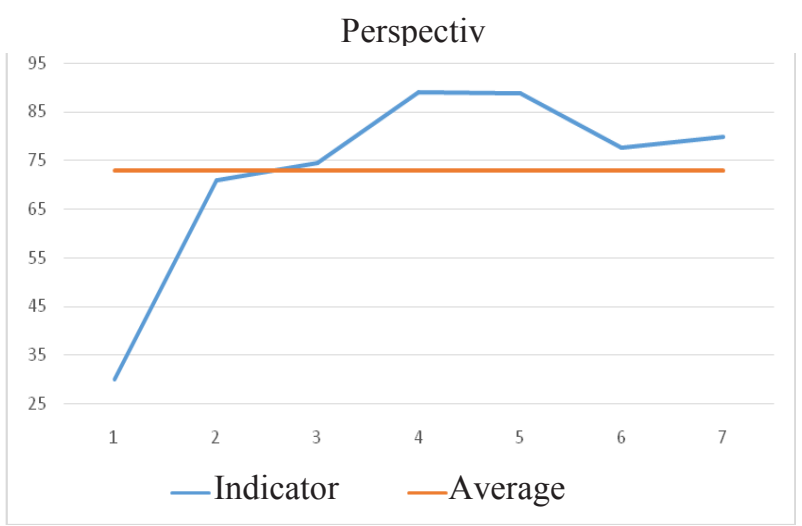

Fig 4. Profile of 'Perspectives' indicator.

We would like to mention something else concerning the results of empirical investigations which prove the possibility of the multilateral evaluation of the singlehood phenomenon.

In 2017, the International Research Laboratory of Wellbeing Improvement Technologies conducted the opinion poll among elderly people in the age of 55 and older living in the Tomsk region. According to results of the opinion poll, statistically significant data were obtained for a number of external and internal factors influencing the feeling of loneliness. External factors include the government policy in relation to elderly people, a fear of helplessness and the absence of assistance when appropriate, the absence of job offers and the non-involvement in social activities. These factors significantly elevate the feeling of loneliness.

Among internal factors, we emphasize the estimation of perspectives and a positive thinking about the events ongoing in the life of elderly people. Statistically significant relations are identified between the feelings of loneliness and happiness, self-satisfaction and satisfaction with his or her life.

\section{Conclusions}

The findings of our research are quite convincing and include:

1. rationale for the evaluation methodology of the singlehood phenomenon observed among elderly people, which is based on the system of indicators and measurable parameters;

2. the model implementation when developing tools for conducting the opinion poll concerning the problems of elderly people in the Tomsk region (2017);

3. setting objectives for validity test of the integrated model of the singlehood phenomenon and evaluation procedures for its level in the social group of elderly people.

From the standpoint of the proposed level model based on understanding the fact that loneliness is caused by social and economic reasons, the phenomenon of singlehood should be considered as the indicator (sign) of the state of society as a whole, which describes the human satisfaction with living conditions.

Thus, the integrated modeling of the singlehood phenomenon among elderly people allows us to 
consistently make the way from the model of vision of this phenomenon and systemic model of its evaluation to the system of indicators and parameters which identify the main processes of the phenomenon under study.

The research was financially supported by the RFBR within the research project «Development of comprehensive assessment of the efficiency of senior citizens involvement in regional community», project no. 19-010-00984.

\section{References}

1. L. I. Shcherbakova and E. N. Azarova, Social singlehood in transforming Russian society: institutional approach Socio-humanitarian knowledge 7, 144-148 Retrieved from: http://naukarus.com/sotsialnoeodinochestvo-v-transformiruyuschemsya-rossiyskomobschestve-institutsionalnyy-podhod/.(2013).

2. S. Ilardi, Social isolation: A modern plague, In Psychology Today, (2009).

3. G.C. Wenger, R. Davies, S. Shahtahmasebi and A. Scott, Social isolation and loneliness in old age: review and model refinement, In Ageing and society 16(3), 333358 (1996).

4. E. Erikson, Childhood and Society (SaintPetersburg: Lenato, ACT, Fond Universitetskaya kniga, 1996).

5. E. Yu. Kakhanova, Integrated potential of the individual's feeling of loneliness as a method of empirical data processing in long life research, Bulletin of the Krasnoyarsk State Pedagogical University. V.P. Astafieva 1 (27), 160-164 (2014), Retrieved from: http://cyberleninka.ru/article/n/integralnyy-potentsialperezhivaniya-odinochestva-lichnostyu-kak-metodobrabotki-empiricheskih-dannyh-v-lonlinologicheskom/

6. Zh. V. Puzanova, Singlehood as an object of empirical analysis, Sociology: methodology, methods and mathematical modeling 29, 132-154 (2009).

7. L. F. Berkman, L. S. Syme, Social networks, host resistance and mortality: a nine-year follow-up study of alameda county residents, In American Journal of Epidemiology 2, 186-204 (1979).

8. H. B. Gibson, Loneliness in later life (New York: Palgrave Macmillan, 2000).
9. E. A. Anikina, G. A. Barysheva, I. V. Gumennikov et al., Social, economic and emotional wellbeing of elederly people in Russia: social and retirement policy (Tomsk: STT, 2018).

10. M. E. Elyutina, O. A. Trofimova, Lonely living and loneliness in elderly age, Journal of Social Policy Studies 15 (1), 37-50, (2017).

11. O. V. Miller, Social networks as a way to solve the problem of singlehood among elderly people, Innovative science 7-2, (2015), Retrieved from: http://elibrary.ru/item.asp?id=23891246/

12. J. C. Goll et al., Barriers to social participation among lonely older adults: the influence of social fears and identity, In PLOS One, 10 (2), (2015).

13. D. Zavaleta, K. Samuel and C. T. Mills, Measures of social isolation, In Social Indicators Research 131 (1), 367-391 (2017).

14. C.R. Victror, S.J. Scambler, A. Bowling and J. Bond, The prevalence of, and risk factors for, loneliness in later life: a survey of older people in Great Britain, In Ageing and society 25(3), 357-375 (2005).

15. W. A. Sadler T. B. and Johnson, From Loneliness to Anomia. In: Labyrinths of loneliness (Moscow: Progress, 21-51, 1989).

16. D. Perlman and L. A. Peplau, Theoretical approaches to loneliness, Labyrinths of loneliness (Moscow: Progress, 152-168, 1989).

17. V. Sermat, Some situational and personality correlates of loneliness, In: Labyrinths of loneliness (Moscow: Progress, 227-242, 1989).

18. C. M. Perissinotto, I. S. Cenzer and K. E. Covinsky, Loneliness in older persons: a predictor of functional decline and death, In Archives of Internal Medicine 172 (14), 1078-1084, (2012).

19. J. T. Cacioppo et al., Loneliness as a specific risk factor for depressive symptoms: cross-sectional and longitudinal analyses, In Psychology and Aging 21(1), (2006).

20. J. Holt-Lunstad, T. B. Smith and J. B., Layton Social relationships and mortality risk: a meta-analytic review, In PLOS Medicine 7 (7), (2010). 